\title{
Cattle Consumption of Velvet Lupine (Lupinus leucophyllus) in the Channel Scablands of Eastern Washington
}

\author{
Michael H. Ralphs, ${ }^{1}$ Kip E. Panter, ${ }^{1}$ Clive Gay, ${ }^{2}$ \\ Ernie Motteram, ${ }^{2}$ and Stephen T. Lee ${ }^{1}$ \\ Authors are with the ${ }^{1}$ USDA/ARS Poisonous Plant Research Lab, Logan, UT 84341; and \\ ${ }^{2}$ Field Investigative Unit, Veterinary School, Washington State University, Pullman, WA 99164.
}

\begin{abstract}
Certain lupines (Lupinus spp.) contain alkaloids that cause contracture-type skeletal birth defects and cleft palate ("crooked calf syndrome") when consumed by cows during the 40th to 70th day of gestation. The objective of this study was to determine when cattle graze velvet lupine (Lupinus leucophyllus Dougl.) during its phenological development, and whether this period overlaps the critical period of gestation. Grazing studies were conducted in 2001, 2002, and 2003 in the same 100 ha pasture in eastern Washington. A second objective was addressed in 2001 to determine if cows with crooked calves consumed more lupine than cows with normal calves. Five mature Hereford cows with crooked calves at their side and 6 mature Hereford cows with normal calves grazed together for the summer. There was no difference $(P=0.17)$ in the amount of lupine consumed between groups, and all cows consumed some lupine. In 2002, 10 3-year-old Hereford cows with normal calves were used, and in 2003, 8 of the same cows from the 2002 study with normal calves were used. In all 3 years, cows started consuming lupine in July and August after annual grasses dried and annual forbs matured. Lupine is a deep-rooted perennial that remained green and succulent longer into the summer than the associated forages. Concentration of the teratogenic alkaloid anagyrine declined as lupine seeds shattered in late June and early July. Lupine consumption occurred during the critical period of gestation in 2 of the 3 years, but no crooked calves were produced. Apparently, the cows did not ingest sufficient amounts of anagyrine over the susceptible period of time to produce crooked calves. The management recommendation for this site is to restrict access to lupine during July when cattle begin to graze lupine and anagyrine levels may still be relatively high. Once the seeds shatter, toxicity greatly declines.
\end{abstract}

\section{Resumen}

Ciertos "Lupines" (Lupinus spp.) contienen alcaloides que cuando son consumidos por las vacas entre los días 40 al 70 de la gestación causan defectos congénitos del tipo de contractura del esqueleto y paladar hendido (síndrome del becerro encorvado). El objetivo de este estudio fue determinar en que etapa fenológica del desarrollo del "Velvet lupine" (Lupinus leucophyllus Dougl.) es consumido por el ganado y si este periodo se traslapa con las etapas críticas de la gestación. Los estudios de apacentamiento se condujeron en el 2001, 2002, y 2003 en un mismo potrero de 100 ha ubicado al este de Washington. Un segundo objetivo se planteó en el 2001 para determinar si las vacas con becerros encorvados consumieron más "Lupine" que las vacas con becerros normales. Cinco vacas maduras de la raza Hereford con becerros encorvados y seis vacas maduras de la misma raza con becerros normales apacentaron juntas en el verano. No hubo diferencia entre grupos de vacas $(P=0.17)$ en la cantidad consumida de "Lupine," y todas las vacas consumieron algo de "Lupine." En el 2002, se usaron 10 vacas de la raza Hereford de 3 años de edad con becerros normales y en el 2003 ocho vacas con becerros normales de ese estudio fueron utilizadas. En los tres años las vacas iniciaron el consumo de "Lupine" en Julio y Agosto después de que los zacates anuales se secaron y las hierbas anuales maduraron. El "Lupine"es una planta perenne de raíz profunda que en el verano permanece verde y suculenta por más tiempo que los forrajes asociados. La concentración del alcaloide teratogénico anagrina disminuyó conforme las semillas de "Lupine" se dispersan a fines de Junio e inicios de Julio. En dos de los tres años, el consumo de "Lupine ocurrió durante el periodo crítico de la gestación, pero no se produjeron becerros encorvados; aparentemente, porque las vacas no ingirieron la cantidades suficientes de anagrina durante el periodo susceptible de la gestación. La recomendación de manejo para este sitio es restringir el acceso al "Lupine" durante Julio cuando el ganado comienza a consumirlo y los niveles de anagrina todavía pueden estar relativamente altos. Una vez que las semillas han sido liberadas la toxicidad disminuye grandemente.

Key Words: birth defects, cattle grazing, poisonous plant, lupine

\section{INTRODUCTION}

Correspondence: Michael H. Ralphs, USDA/ARS Poisonous Plant Lab, 1150 E 1400 N, Logan, UT 84341. Email: mralphs@cc.usu.edu

Manuscript received 28 October 2005; manuscript accepted 26 November 2005.
Many common lupine (Lupinus spp.) species contain quinolizidine and piperidine alkaloids that can be toxic and/or teratogenic to livestock. Calf losses from congenital birth defects have been reported in several western states (Panter 
et al. 1997). Ingestion of lupine by the dam during the 40th to 70th day of gestation can cause a crooked calf syndrome (Shupe et al. 1967). The quinolizidine alkaloid anagyrine (Keeler 1976) and some piperidine alkaloids (ammodendrine and N-methyl ammodendrine) cause the crooked calf syndrome by reducing fetal movement during this critical period of gestation (Panter et al. 1990), causing the spine and limbs to develop in contracted or malformed positions.

Keeler et al. (1977) proposed a simple management solution: stagger grazing of lupine-infested pastures so that the susceptible period of gestation does not overlap the flower and pod stage of growth when anagyrine is highest. However, this recommendation does not consider when cattle are likely to graze lupine. The principal objective of this study was to determine when cattle graze velvet lupine (Lupinus leucophyllus Dougl.) in the channel scabland region of eastern Washington, to and determine if it overlaps the critical stage of gestation. A second objective was addressed in 2001 to determine whether those cows that had crooked calves had a propensity to consume more lupine than those with normal calves.

\section{METHODS}

The study site was in the channel scabland region of eastern Washington about $25 \mathrm{~km}$ southeast of Ritzville (lat $46^{\circ} 15.347^{\prime}$, long $\left.118^{\circ} 13.031^{\prime}\right)$. The original plant community was a palouse prairie but has been degraded to annual species, such as cheatgrass (Bromus tectorum L.), fiddleneck (Amsinckia intermedia Fisch, \& Mey), tansy mustard (Descurainia pinnata [Walt.] Britt), and rush skeleton weed (Chondrilla juncea L.). Horsebrush (Tetradymia canescens D.C.) and rabbitbrush (Chrysothamnus nauseosus [Pallas ex Pursh] Britt.) were dominant sprouting shrubs, which suggests a relatively frequent fire regime. Average density of velvet lupine was 1.5 plants $\cdot \mathrm{m}^{-2}$. The experimental pasture was about 100 ha and was fenced off from a larger pasture using temporary electric fence. The pasture was considered a high-risk pasture as the rancher had sustained crooked calf losses in the past.

\section{Group Comparison 2001}

The objective of the first trial was to compare lupine consumption between cows that had crooked calves and those with normal calves. The hypothesis was that cows with crooked calves had a greater propensity to graze lupine than those with normal calves. Five mature Hereford cows with crooked calves at their side and 6 mature Hereford cows with normal calves were obtained from a local rancher. Cows averaged $550 \mathrm{~kg}$, and calves were about 2 months old when the study began. The groups grazed together in the pasture, and individual cows were considered the experimental units. The study began 10 May as lupine was beginning to grow, and ended 3 August when lupine had senesced. Animals were handled by methods approved by an Institutional Animal Care and Use Committee.

Diet composition was estimated by a bite count technique (Ortega et al. 1995). Each cow was observed for 5-minute periods during the morning and evening grazing periods. Each cow was observed at least once during each grazing period, but generally from 4 to 5 times each day. The number of bites of forage classes (perennial grasses, annual grass, forbs, and lupine) were recorded, and their percentage of diet was calculated. Percentage diet data were arc sine transformed prior to analysis to meet the assumption of normality. Percentage of bites of each forage class was analyzed using a repeated measures mixed model analysis of variance (SAS Institute Inc, Cary, NC) comparing groups over weeks of the trial using compound symmetry covariance structure. There was no difference in lupine consumption between cows with crooked calves and cows with normal calves in $2001(P=0.17)$. There were no crooked calves in the region in 2002 or 2003; therefore the group comparison was discontinued.

\section{Seasonal Palatability}

Diet data for the 2 groups were pooled for 2001 and compared with other cows grazing the same pasture in 2002 and 2003. The main objective of the larger study was to determine when cattle grazed velvet lupine. In 2002, 10 different 3-year-old Hereford cows along with their calves grazed from 4 June to 14 August. In 2003, 8 of the same cows (one cow broke her leg and another was culled) along with their new calves grazed from 14 May to 18 August. Diets were quantified by bite counts as described above. Means and standard errors are presented to describe the patterns of lupine consumption.

A mature Hereford bull was placed in with the cows each year around 10 May. The date that each cow bred was recorded. Based on the breeding dates, the susceptible period of gestation (40th to 70th day of pregnancy) was calculated and compared to the time lupine was consumed.

Standing crop was sampled at the beginning, midseason when cheatgrass had matured, and at the end of each year's study. Composite samples of each forage class was analyzed for crude protein by means of total N (LECO model FP-528; LECO Corp, St Joseph, MI) and neutral detergent fiber (NDF) (ANKOM200 fiber analyzer; ANKOM, Fairport, NY).

Lupine samples were collected at approximately 2-week intervals during the study each year. Ten uniform plants were harvested at each collection, ground, and analyzed for anagyrine using a gas chromatograph method (Gardner and Panter 1994). Improvements to the previously described procedure included the use of caffeine as an internal standard, and concentration of anagyrine and other major alkaloids was quantified against a 6-point standard curve (S. Lee, unpublished method, 2004). Correlations were run between anagyrine concentration and lupine bites in diets.

\section{RESULTS AND DISCUSSION}

Cattle started grazing lupine around the first of July each year (Fig. 1). The average amount of lupine consumed in July and August was $6.1 \pm 0.66$ (SE) \% of bites in 2001, $5.9 \pm 0.34$ in 2002 , and $3.4 \pm 0.30$ in 2003 . The timing of lupine consumption was similar in all 3 years and was dependent on the availability and maturity of the associated forages.

Cattle selected annual grasses while they were still green during the first part of the season each year (Fig. 1). Crude protein content of cheatgrass was $8.5 \%$ at the beginning of the season, but declined to $5 \%$ after it dried. As the annual grasses matured and dried, cattle selected green forbs, such as fiddleneck, rush skeleton weed, and tansy mustard, during the mid- 


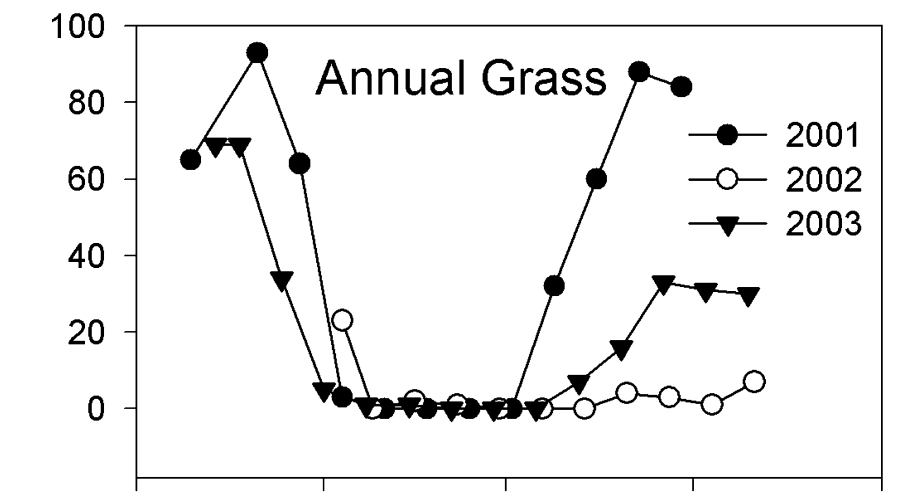

Anagyrine in plants and Lupine in diets
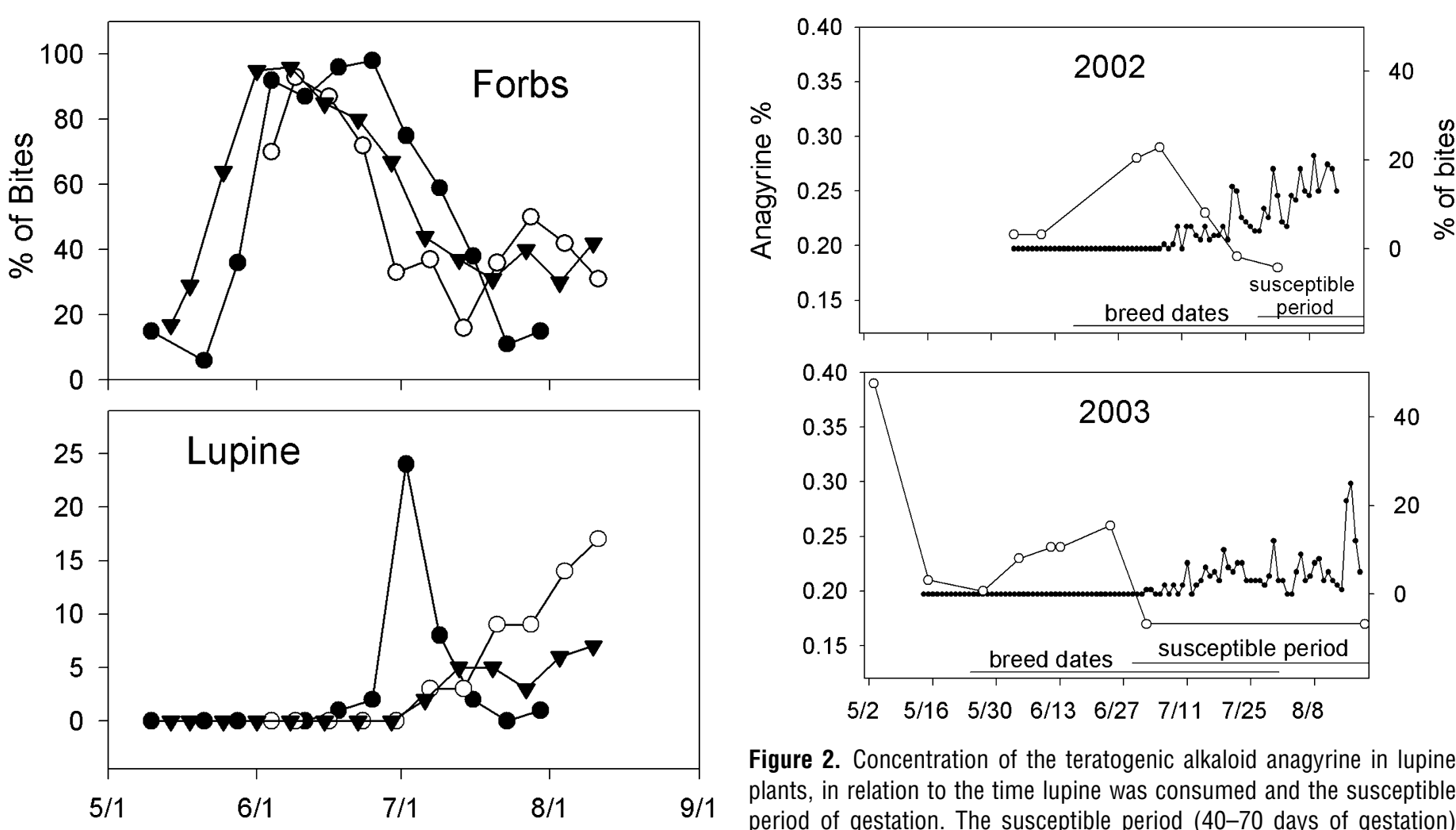

Figure 1. Annual grasses, forbs, and lupine in cattle diets in 2001, 2002, and 2003 in the channel scablands of eastern Washington.

dle part of the summer (Fig. 1). Crude protein of forbs ranged from $10 \%$ to $14 \%$ during the first half of the season, and fiber content (NDF) averaged $55 \%$, compared to $65 \%-70 \%$ in annual grasses. As these forbs were depleted or matured and dried, cattle began selecting the deep-rooted lupine (Fig. 1), which remained green and succulent longer than the other forbs. Crude protein content of lupine was $15 \%$ through the middle part of the season, and NDF remained below 55\%. Although it was the most nutritious forage throughout the season, cattle did not graze it until the other forages were depleted or matured. We suspect its dense pubescence contributed to its lack of palatability. Lopez-Ortiz (2002) also reported that cattle selected velvet lupine only after annual grass and other forbs became limited in a grazing study in the same area.

The general breeding season in this region is 1 May to 30 July. Therefore, the susceptible period of gestation (day 40 70) runs from 10 June to 8 October. Breeding dates in our study

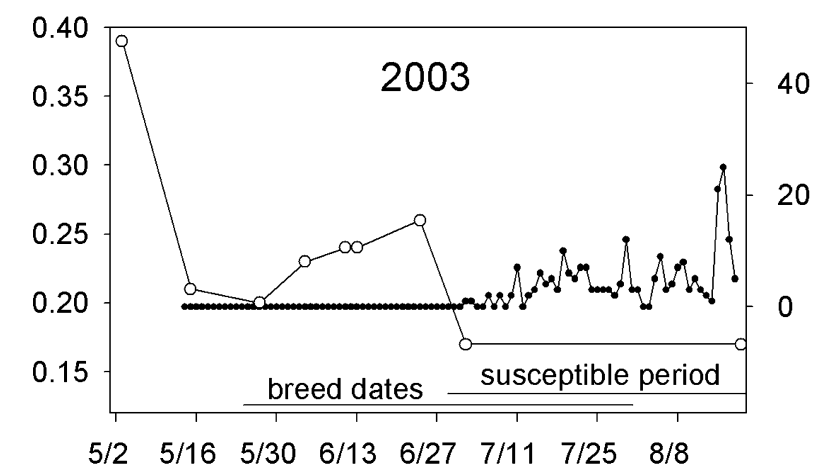

Figure 2. Concentration of the teratogenic alkaloid anagyrine in lupine plants, in relation to the time lupine was consumed and the susceptible period of gestation. The susceptible period (40-70 days of gestation) was calculated from the actual breed dates.

ranged from 20 May through 30 August. Since our cows consumed lupine during July and August, ingestion of the teratogenic alkaloid anagyrine occurred during the critical period of gestation in 2002 and 2003 (Fig. 2).

There was a weak negative correlation between anagyrine and lupine consumption in $2002(r=-0.50, P=0.17)$ and $2003(r=-0.67, P=0.01)$ (Fig. 2). These negative correlations reflect the declining concentration of alkaloids following seed shatter, which is when the cows started eating lupine around the first part of July. The high levels of total alkaloids during the flower and pod stage of growth may have contributed to its lack of palatability.

\section{MANAGEMENT IMPLICATIONS}

Lupine was consumed by all cows during July and August each year, which overlaps the critical period of gestation (10 June to 8 October). Anagyrine concentration was highest during early 
growth and in the flower and pod stage in June, then rapidly declined in early July once the seeds shattered. This information can be used to refine Keeler et al.'s (1977) management recommendation on this site, from restricting access to lupine during the entire critical gestation period, to restricting access only during early July when cattle are likely to eat it and anagyrine concentration is still high. Once the seeds shatter, anagyrine concentrations should be below the threshold to cause crooked calves.

\section{LITERATURE CITED}

Gardner, D. R., and K. E. Panter. 1994. Ammodendrine and related piperidine alkaloid levels in the blood plasma of cattle, sheep and goats fed Lupinus formosus. Journal of Natural Toxins 3:107-116.

KeELER, R. F. 1976. Lupin alkaloids from teratogenic and nonteratogenic lupins. III. Identification of anagyrine as the probable teratogen by feeding trials. Journal of Toxicology and Environmental Health 1:878-889.
Keeler, R. F., L. F. James, J. L. Shupe, and K. R. Van Kampen. 1977. Lupine-induced crooked calf disease and a management method to reduce incidence. Journal of Range Management 30:97-102.

LOPEZ-ORTIZ, S. L. 2002. Nutritional status, dietary preferences and response to toxicosis of livestock exposed to lupine (Lupinus spp.) [dissertation]. Moscow: University of Idaho. $110 \mathrm{p}$.

Ortega, I. M., F. C. Bryant, and D. L. Drawe. 1995. Contrasts of esophageal-fistula vs. bite-count techniques to determine cattle diets. Journal of Range Management 48:498-502.

Panter, K. E., T. D. Bunch, R. F. Keeler, D. V. Sisson, and R. J. Callan. 1990. Multiple congenital contractures (MCC) and cleft palate induced in goats by ingestion of piperidine alkaloid-containing plants: reduction in fetal movement as the probable cause. Clinical Toxicology 28: 69-83.

Panter, K. E., D. R. Gardner, C. C. Gay, L. F. James, R. Mills, J. M. Gay, AND T. J. BaLdWIN. 1997. Observations of Lupinus sulpureusinduced crooked calf disease. Journal of Range Management 50: 587-592.

Shupe, J. L., W. Binns, L. F. James, and R. F. Keeler. 1967. Lupine, a cause of crooked calf disease. Journal of the American Veterinary Medical Association 151:198-203. 